\title{
整合操作に着目した企画設計 CAD の開発研究 \\ ON THE DEVELOPMENT OF SCHEMATIC DESIGN CAD THAT SUPPORTS ADJUSTMENT OPERATIONS AMONG MULTIPLE REPRESENTATION MODELS
}

下川雄一*, 両角光男**, 位寄和 久**, 本間里見*** Yuichi SHIMOKAWA, Mitsuo MOROZUMI, Kazuhisa IKI and Riken HONMA

\begin{abstract}
Designers generally develop their designs as processes of adjusting and reconciling design decisions explored using various types of representation models that were developed, in parallel fashion, to study varying subjects such as space planning, building bulk, or structural system.

Though the most CAD allow users to define multiple representation models, they have lacked utilities that support adjusting operations among them.

It is the objective of this study to propose a model of design process and a prototype $\mathrm{CAD}$ for schematic design stage.

Reviewing a case study, the authors assessed the advantages of the system use and subjects for the future studies.
\end{abstract}

Keywords: CAD, Modeling, Design thinking, Adjustment operation, Design process model $\mathrm{CAD}$, モデリング, 設計思考, 整合操作, 設計プロセスモデル

1. 研究の目的と方法

これまで国内外の研究者が建築設計者の思考プロセスに馴染む 道具の開発」に取り組んできた。とりわけ 3 次元モデリング機能を 持つCAD（以下，CADと略す）は，物体の形状を直接定義でき る上,図面システムにおける記述調整の煩雑さや記述内容の不整合 を回避できるため, 重要なテーマとなっている。しかし，曖昧なイ メージを徐々に具体化し建築モデルを定義していく企画設計段階の 道具としては，未だ検討すべき課題が残されている。

企画設計段階の作業を観察すると，設計者は建築の平面，外形， 構造など,複数の観点から目的に応じた表現形式のモデルを並列的 に定義し注1), 徐々に擦り合わせ（以下,「整合操作」と呼ふ）なが ら設計案をまとめていくことが多い。例えば長倉は, 先ず平面計画 を検討し，次に立面・断面図を使って高さを検討，次いで 3 次元モ デルを使って空間や建築形態を検討するのが代表的な設計手順の一 つと述べている文1)。筆者らが国内外の設計事務所を対象に設計手順 や C A D の利用状況を訪問調査した際には, 複数の観点から幾つか のモデルを定義しながら並列的に検討を進めているのが何れの事務所 でも観察された洁2)。ところが一組の3次元モデルを定義することを 前提にした在来の C A D では, 複数の観点からの検討を独立して行 うことが困難である。これが逆に, 特定の観点からの決定を保留し
たまま作業を進める等の企画設計の過程に求められる定義の柔軟さ を奪い，3 次元モデルの活用を制約してきたことも否定できない注 3)。市販の C A D でも目的に応じたモデルを並列的に定義できるが， 相互にデー夕を連携させたり, 異なるモデルを確実に擦り合わせて いく機能が未発達である。

本研究の目的は,複数のモデル間の整合操作に着目した企画設計 支援 C A D を開発することである。手順として, 先ず筆者らの研究 室で行った設計プロセスの事例を分析し,整合操作による企画設計 の作業モデル注4)を提案する。次に, 在来 C A D の限界と整備すべき 機能や,「モデル空間」「プランフェース/セクションフェース」から 成る作業環境の仕様を提案する。最後に試作システムでは,在来の C ADに比べ設計案の検討や代案の定義が容易になることを示し,提案 したシステムの仕様・機能の有効性を検証する。

\section{2、既往の関連研究}

設計思考に対応したCADの機能・仕様を提案した研究には, 主 としてシステムが扱う設計案の記述モデルに関する研究と, 記述し たモデルの編集操作機能に関する研究がある。前者については, 先 ず，建築の部材構成や空間構成の基本型を記述するモデル（意味モ デル）の研究がある。CADにモデルを参照させることにより，設
* 金沢工業大学環境・土木・建築系 助手・工修

** 熊本大学工学部環境システム工学科 教授・工博

*** 熊本大学工学部環境システム工学科 助手
Instructor, Kanazawa Institute of Technology, M. Eng.

Prof., Dept. of Architecture and Civil Engineering, Faculty of Engineering, Kumamoto University, Dr. Eng.

Instructor, Dept. of Architecture and Civil Engineering, Faculty of Engineering, Kumamoto University 
計案の定義や評価の作業を効率化したり,企画段階の検討事項を基 本設計や生産設計など後段の作業に的確に伝達するなどが狙いであ る。企業や渡辺らがそれぞれの枠組みに従ってモデルを提案し，C ADを試作した注5)。最近は各種団体の国際協力によって I F C P S $\mathrm{T}$ E P 等, モデルの標準化が検討されている。これらの研究は建築 として具体的に定義された段階の記述に主眼が置かれており,設計 者の暖昧なイメージを具体的な建築モテルに置き換えていく過程の 記述に関する検討が不足している。これに対し藤原ら文2)は,イメ一 ジが具体化する過程で抽象度の異なる 2 次元や 3 次元の中間モテル が存在することを示した。また西郷ら文い) は設計者の描いたスケッ チの分析を基に, 企画設計段階で少なくとも 3 群 7 タイプの中間モ デルが使われることを示し，C A D が扱うべき意味モデルの特徵と その操作性を提案した。

モデルの編集操作機能に関する研究については, 無重力の世界で 粘土を加エするような操作性の高いシステムを提案したKurmann文 4 ) やMatthews (文) が新しい。これらは建築外形や建築部材の形状を 定義する道具としては興味深いが, 平面計画を試行錯誤する機能に ついては特に考虑されていない。Mitchell文6) はトップ・ダウンと 呼ぶ平面や立面のスケッチ ・ システムを提案した。図形制御枠（以 下, 制御枠と呼ぶ) 内に任意の図形を定義すると, 制御枠の大きさ の変更に伴って内部の図形も自動的に変形する機能,制御枠内の図 形を他の図形と置換する機能,制御枠を再分割する機能を備えてお りトッップダウン的に平面や立面を試行錯誤することができる。ま たBonn文 7) は 3 次元図形を置換しながら段階的に詳細な 3 次元モテ ルを定義していくシステムを提案した。現実にはトップダウン的な 手順だけで設計が進むことは希で,これらのシステムで扱える設計 案には制限があるが, 置換操作自体は抽象度の異なる中間モデルを 組み合わせながら案を具体化するための機能として意義深い。

一方，平面計画を支援するシステムの機能に関しては，高本文8) が線分の接続関係や位置関係を逐次 C A D に認識させることにより， 部分的な設計変更に対して, 通り芯と壁, 柱, 開口部など設計者か 意図した建築部材の位置関係や接続関係に従って関連部分の図面を 自動修正するシステムを提案した。またBranko文9 は, 通り芯を描 き，その交点を手がかりに平面・立面・断面を記述すると，通り芯 の移動:回転に応じて関連する図面の一部が自動修正されるシステ ムを提案した。更に, 両角ら文10)は西郷やミッチェルの研究に対応 する形で,スケッチ・システムを試作した。空間の境界を表す線分 を適宜入力していき,閉じた領域が形成された段階でその領域を部 屋や床などの空間要素としてシステムに認識させる方法で, それ以 降における編集操作の対話性を高めた。更に, 空間の境界線上に建 築部材を代表する直方体の制御枠を配置し, 制御枠内に任意の 3 次 元図形を定義すると, 平面計画の変更に応じて制御枠やその中の部 材の位置や大きさも自動調整するという機能が組み込まれている。 高本やBranko等が提案する通り芯を手がかりにした操作の導入が課 題となっていた。下川ら文11 は, 通り芯や制御枠, 置換操作等の考 え方を 3 次元に展開した構造計画検討システム注6)を提案した。3次 元空間に任意に配置した通り芯の交点を手がかりに部材配置線を定 義し，その部材配置線に浻って部材のボリュームを表す制御枠を配 置する。更に，制御枠内に任意の形状を持つ部材を定義し，それら を置換しながら段階的に軸組形式あるいは壁式の構造モテルを定義

するシステムである。通り芯の移動に応じて部材の接続関係を保ち ながら形状や大きさを自動調整したり，制御枠を分割しながら部材 の詳細を定義することができ, 部材配置線方向の長さについて制御 枠の固定部分と可変部分を指定する機能も提案している。このよう に, 平面; 外形, 構造など目的別の設計案検討システムは幾つか提 案されてきた。しかし，複数の記述モデルを参照しながらデータを 連携させたり, 異なる記述モテルを確実に擦り合わせて行くような 機能が未発達である。

\section{3. 整合操作の繰り返しによる設計案検討の作業モデル}

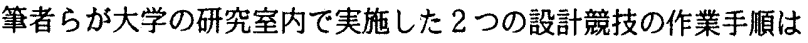
必ずしも特殊ではないとの仮定の下に，作業内容を分析し注7)，並列 的に複数の記述モデルを検討しながら進む設計案検討過程の特徵と， 並列的であるが故に必要となる各種モテル間の整合操作の特徵を考 察する。以降, 平面計画, 外形デザイン, 構造計画の検討のために 定義されたモデルをれそれ平面モテル; 外形モデル, 構造モデル と呼ぶ。また，記述モテル間の整合性確認のために記述される断面 図を断面モテルと呼ぶ。

\section{1 整合操作に着目した設計事例分析}

[事例 1 : 日仏文化会館設計競技応募案の設計過程(1990)] ]

前半は外形モデルと平面モテルを並行して作成しながら検討を進 め, 後半は両者に対して構造的な検討を加える形で設計が進んだ。 表 1 は大まかな作業の流れである。図 1 の(a)〜(d)はそれそれ表 1 の(2), (3), (4)，(6)の段階で作成されたモデルの例である。

[事例 2 : 国立国会図書館関西館設計競技応募案の設計過程(1996)] 機能的要求が複雑であり, 設計規模も大きかったことから, 表 2

表 1 事例 1 における設計の流れ

(1)所要室の直方体モテルを積み上げながら建物規模を確認。 (2)建築外形イメージの検討。扇形の全体形の中央にドーム型のホールを収める ことを決定。ホールの大きさ, 建物の要求規模, 街区形状, 䑏接建物の形状, 周囲の眺望点からの眺めなどを手がかりに外形を検討した。

(3)建物外形モテルとドーム型ホールの外形モテルを用いて各階の床形状を割り 出し，それそれに対し機能単位の配置や動線を検討。

(4)動線計画を考虑し，外形案を変更。(ファサード部分の曲面の分割，階段 エレベータシャフトの追加など)

(5)構造計画の検討と平面計画の具体化。

66円形ホールの構造と内部デザインの具体化。ドーム構造の仕組みを単線と円 柱で表現し，検討。ドームの各階床の間に設けた吹き拔けイメージの確認。 (7)外形テザインを洗練する過程で平面計画の修正。 8)要求図である平面図，立面図，断面図の仕上げ。
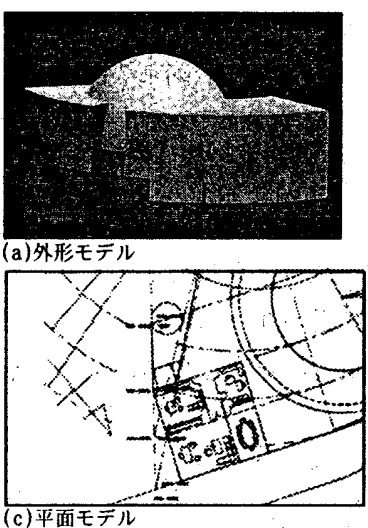

図1事例1における記述モデル

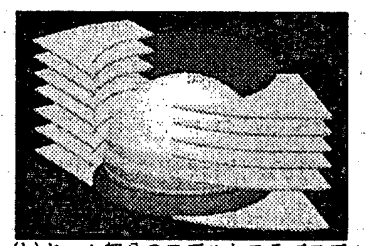

(b)ドーム部分のモテルとスラブモテル

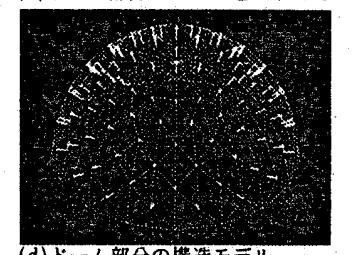

d)ドーム部分の粠造モテル 
に示すように担当を分け，それぞれの検討を同時進行させながら， 徐々に設計案を調整してまとめていった。設計の初期段階では「上 空に浮いた閲覧部門」と「地下書庫」，その間に挟まれた巨大な広場 が共通のイメージとして固まっており（図2の(a))，いかにしてそ れぞれに要求機能を収めるかが焦点となった。表 3 はモデル間の調 整作業を含めた設計過程の概要である。図 2 の $(\mathrm{b})$ ( e $)$ はそれそれ 表 3 の(3)，(4)，(7)，(10の段階で作成された記述モデルやその整合操 作の状態を表したものである。表 4 は記述モデル間の主な整合操作 を作業の目的別に分類したものである。

\section{3 . 2 整合操作による設計過程モデル}

上記 $2 つ$ 設計事例の観察結果から，並列的に進む作業手順の特 徵と各モデル間の整合操作の主な内容を抽出整理した。

[並列的モデリング作業]

a )最終的なモデルの精度や記述内容は必ずしも一定していないが， 西郷の研究を参考に, 取りあえず外形, 平面計画, 構造の三つの 観点に関する次の事項を定義する作業と想定した注9)。

・建物のボリューム, 外形, 仕上げ

・通り芯配置, 床の形状・配置, 階高

- 部屋や通路など空間単位の 2 次元 3 次元的形状 - 配置, 動線

・建築部材やその開口部などの形状・配置・仕上げ

-構造方式, 構造体の基本寸法, 構造部材の形状・配置など

b) 上記を定義するに当たって外形, 平面計画, 構造の各観点からそ れぞれに適した表現の記述モデルを使って並列的に作業が進み， モデル間の整合性を検討する過程で断面モデルが用いられる。ま た各モデルでは西郷が指摘したように抽象的な表現から具象的な 表現へと段階的に中間モデルが置き換えられていく。

c ) 動線計画など機能的な検討は, 形が正確に表現され,柱などの立 体要素が表示を遮ることのない床の正投影画面で行われる。一方, 上下階の紫がりを確認する場合,各階のスラブだけを上下に重ねて 配置し，等角投影視点で作業することが多い。

表 2 事例 2 における作業分担

\begin{tabular}{|c|c|c|c|}
\hline 検璟内容 & モデル & 検討内容 & モテル \\
\hline 筥䈳関係部分の平面と断面（地上 $1 \sim 4$ 階） & 2 次元モテル & 外形 & 3次元モテル \\
\hline 書庫部分の平面（地下 3～4 階） & 2 次元モテル & コア & 3 次元モテル \\
\hline 事務諸室部分の平面と断面（地下 $1 \sim 2$ 階） & 2 次元モテル & 外溝 & 2 次元モデル \\
\hline
\end{tabular}

表 3 事例 2 における整合操作に着目した設計の流れ (1)上空部, 地下部の大まかな所要室ポリューム配分を決定。 (2)手書きスケッチで上空部の平面外形を決定。並行して,地下書庫の平面外形 および基準寸法を独自に決定。

(3)上空部分の纳の床形状を定義し，機能配置や動線計画を検討。その後，床形 状をもとに 3 次元の外形モデルを作成する。

(4)上空部の外形の上下左右各面に曲面が用いられたため,断面モテルから平面 で利用可能な休の範囲を割り出し，各階床形状を変更。

(5)上空部の平面で定義された通り芯を手脚かりに，3次元モデルを作成しなが ら上空部とそれを支えるコアの構造計画を検討。

(6)構造解析の結果とコア周りの動線計画(階段とエレベータ)を考慮し,柱の スパンを変更。それに伴い上空部と地下書庫で柱割, コアの位置を調整。更に 通り芯を手掛かりに外形と構造モデルを再定義。

(7)上空部と地下部で,搬送装置，吹き抜け，エレベータの位置を繰り返し確認 しながら計画を詰める。

8)地下 1 階と外溝で，来館者，VI P，搬入の動線を調整。

(9面積計算の手違いによる地下書庫の基準寸法変更。これに伴って上空部のス パンを一部変更し，更に外形と構造モデルを調整。

(10構造体に筋かいを追加。断面図を描き，各階の床レベルにおける動線への影 響を確認し，平面計画を調整。

(11)上空平面を微調整しながら外形との整合性を繰り返し確認。

(12)提出用各種モデルの仕上げ。 d）外形モデルと構造モデルは基本的に 3 次元モデルとして作成さ れる。特に，外形モデルは建物全体を表す抽象的なボリュームモ デルとして表現され, 構造モデルは通り芯や応力線, 単純な幾何 立体の集合として表現され，徐々に複雑な形状に置き換えられる。 [モデル間の整合操作]

検討内容の大きな流れとしては外形 $\rightarrow$ 平面計画 $\rightarrow$ 構造, 平面計画 $\rightarrow$ 外形 $\rightarrow$ 構造の 2 種類が代表的であるが，いずれにしてもその移行 の過程で次のような整合操作が必要となる。

e ）各階床レベルで外形モデルの断面形状を表す図形（以下，断面 図形と呼ぶ）を取り出し，それを基に平面モデルの外形を定めた り，高さ検討のため垂直方向の断面図形を取り出したりする。

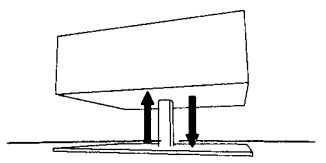

(a)最初のコンセプトモテル

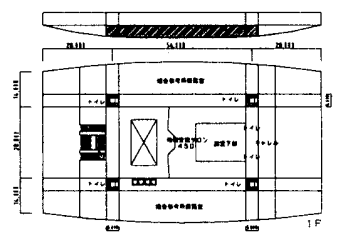

(c)外形断面を参照しながら平面を㛟討 (b)外形と構造のモデを重ねた状態 外形の底面と水平材とに矛盾が見られる

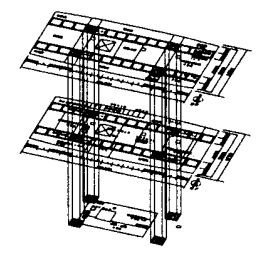

（d）各階平面を上下に重ねて綎動線を確認
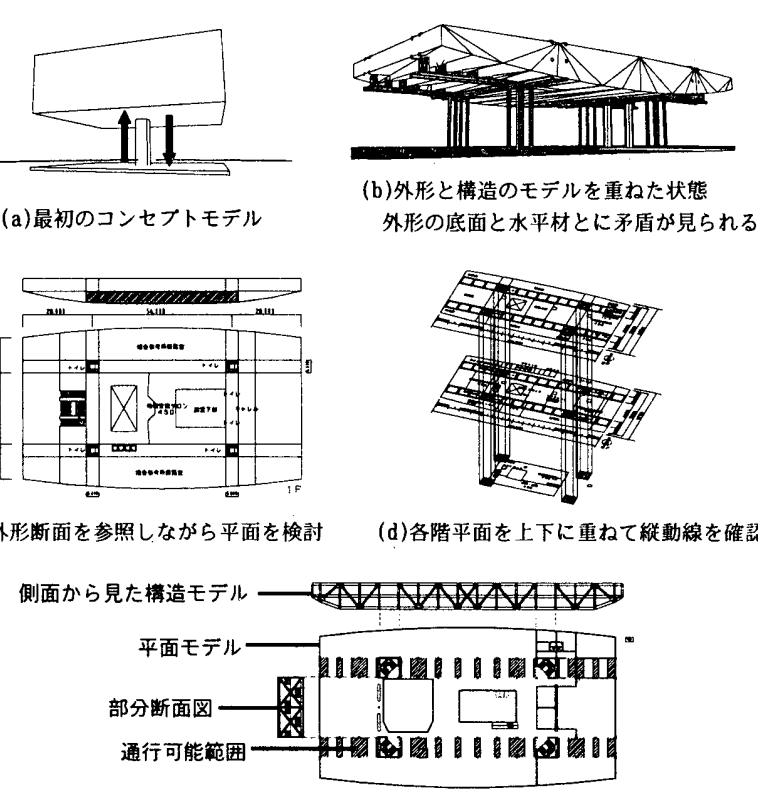

（e）構造モテルと平面モテルの摖り合わせ

図 2 事例 2 における記述モデル

表 4 事例 2 における整合操作の事例

タイプA:設計変更に伴う最新デー夕の伝達

(1)スパンの変更。新しい通り芯のデータが配られる。関連するモデルでは新し い通り芯に合わせて調整を行う。各階平面モテルは標準のコマンドで修正し， 構造や外形モテルはその通り芯に合わせて作り直す場合が多かった。

(2)各階平面の変更。平面モデル間で, 垂直動線や吹き抜け, コア出入口, 建物 の外形など,該当部分のテータを受け渡し,それそれでモデルの位置合わせ， 及び調整を行う。

タイプB：モデルの新規作成及び更新

(3)三次元の構造モテル作成。平面モデル中の通り芯や建物の外形線を構造担当 者へ受け渡し，それらを基に 3 次元の構造モテルを作成する。

(4)三次元の外形モデルの作成。平面モデルから通り芯や外形線を, 断面から外 形線を受け取り，そ扎をを組み合わせながら外形モデルを作成。

(5)平面モデ作成。三次元の構造モデルの柱・梁・筋かいなどを 2 次元モデル に投影する。断面線や見え掛り線を取り出して平面担当に受け渡し，平面モ テルや断面モデ上に配置する。

6断面モテル作成。地下部分は平面モデルから通り芯や壁の位置を割り出しな がら作成。地上部分は 3 次元の構造モデルから部材の断面線を取り出し, 平 面と突き合わせながら作成。

タイプC : モデル相互の整合性の確認

(7)三次元の構造モデルの平面モデルへの影響を確認するために,部材モデルの 断面線を取り出し, 平面モデルと重ねてみる。

(8)平面モデルを上下階同士で重ね合わせ，垂直動線や吹き抜け，搬送装置の位 置・形状の調整を行う。また，機能ボリュームのやり取りによる面積の調整。 (9)外溝モデルと事務諸室平面モデルを重ね合わせて，搬入路やエントランスの 位置・形状の擦り合わせ。

(10平面モデルと断面モテルを上下に位置合わせして併置し,断面モデルから高 さ方向の情報を取得する。 
f ）機能単位のボリュームモデルを積み上げ, 外形モテルとの干涉 関係を確認する。

g) 同一または類似の構成を持つ平面モデルが複数階定義されてい る場合,設計変更に対しては特定部分のモデルを複写する等によ り各階を修正する。単純だが，煩雑な作業であることが多い。

h) : 各階の平面モデルで定義された通り芯や外形モデから取り出 した断面図形を手掛かりにしながら構造モデルを定義する。

i ）各階の平面モデルや外形モデル，構造モデルなど複数のモデル が定義された状態で, 原点や座標軸を合わせながら相互に重ね合 わせたり，横に並べたりしながら全体の関係を検討する。

j ）構造モデルの断面図形を取り出し,平面モデルに重放合わせ,動 線や間取りへの影響を確認する。

k)平面モデルと構造モデルとの調整は通り芯を手掛かりに進める。 各階の平面モデル間でも通り芯を手掛かりに調整することが多い。

1 ) 外形モデル・構造モデルと平面モデルを再調整する際には, 外 形モデルと構造モデルの断面図形の取り出しと平面モテルへの重 ね合わせが繰り返し行われる。

\section{4. 整合操作における在来 C A Dの問題点}

事例 2 の観察を基に, 市販の汎用的な C A D を利用して整合操作 する場合の主要な問題点を以下に挙げる。

1) 断面図形の管理操作 : e)，j），1)などの整合操作に対し，任意 に設定した平面でソリッドモデルの断面形状を図形として取り出 す機能を持つ C A D ${ }^{\text {注10) }}$ は幾つかある。しかし，断面図形を定義 後，一群の図形として表示制御，編集制御するためには，画層の 新規定義, 現在層の変更, 複数の命令の実行とパラメー夕入力を 一定の手順で繰り这す必要があり，煩雑でミスを犯しやすい。

2 ) モデル相互の相対位置関係の視覚表示: 複数の平面モテルや断 面モデルを定義する場合, 各モデルは建物全体に対する定義位置 が決定されているにもかかわらず,「1階平面」「 等のように記号で整理されるに止まり,各モデルの相対的位置関 係を視覚的に確認する機能が無い。

3 ). モデルの重ね合わせや定義位置の調整 : i)の整合操作のように 複数の図形群の一括移動を汎用 C A D 上で行うには，画層の制 御, 図形の選択と移動など複数の命令の実行とパラメータ入力を 一定の手順で繰り返しながら作業する必要がある。特に, 平面モ デルや外形モデルなどの各モデルに複数の画層が定義されている 場合, 特定の図形をモデ間で複写したり，代案を作成したりす ると画層管理が更に複雑になる。

4 ) 複数の平面 (断面) モデルの一括処理：g)の整合操作のように, 上下階のモデルを一括して修正するような場合があるが，そのよ うな作業を支援する機能が無い。

5 ) 通り芯によるモデル間の調整の問題 : 整合操作のh), k)のよう に，各モデル間の調整は通り芯の位置調整により進められていた が,個々のモデルにおいて通り芯とその他の図形要素の関係性を システムが保持していないため,通り芯の位置を変更する度に関 連部分の゙モデルを再定義する必要が生じた。既往研究の項で述べ たような, 通り芯の編集に伴って, それを参照して配置されてい る空間要素や柱や梁などの図形要素群の寸法や位置を自動的に調 整してくれるような機能が必要である。

\section{5. 整合操作支援 C A D システムの仕様}

3 や 4 で述べた作業モデル及び在来 C A D の問題点を踏まえ, 整 合操作を支援するC A D システムの基本仕様について検討した。当 面, 平面モデル，構造モデル，外形モデル，断面モデルによる整合 操作を想定し，その概要を述べる(表 5 )。

(1) モデルの定義空間

(1) モデル空間 : モデル空間は外形モデルと構造モテルの3 次元モ テルを定義するための空間である。また，モデル空間内に後述す る方法で平面モデルや断面モテルを定義することができる。代案 の検討用など，1つのファイル（ワールド座標空間）内に複数の モテル空間を定義できる。各モデル空間はＣＡＤ本来のワールド 座標空間 (以下, W空間と呼ふ）内の任意の位置に定義すること ができ，モデル空間の基準面 (XY平面) はW空間内に長方形の 枠注11) で表示される。また，その枠の頂点の1つがモデル空間の 基準点となる。カーソルで枠, あるいはモテル空間名を表すうべ ル注12)を指示することにより，モテル空間全体の表示状態 (表示・ 非表示）を切り替えたり，ドラッグ操作によりW空間の任意の位 置にモデル全体を一括して移動できる。

(2) 作業平面: プランフェース(P F), セクションフェース(S F ): P F / S F は平面モデルや断面モデルを定義したり，モデル空間 に定義された外形モデルや構造モテルの断面図形（平面も含む） を取り出すための平面である。P F はモテル空間の X Y 平面に対 し平行で任意の高さに定義し，S Fはモデル空間に対し垂直に定 義する(図 3 )。PFやS F はいずれかのモデル空間内で定義され るものとし，対応する位置に長方形の枠で表示される注13)。また， その枠の左下の頂点が其々のP F / S F の基準点となる。 P F / S Fの枠をカーソルで指示することにようて編集可能モデルを指示 したり, 表示状態を切替えたり，また枠のドラッグ操作によりそ れそれに定義されたモテルをW空間の任意の位置に移動できる。

(3) 画層定義 : モデル空間，P F，S F それぞれに複数の画層を定 義できる。各画層は C A D の基本機能で個別に操作できるが, 枠

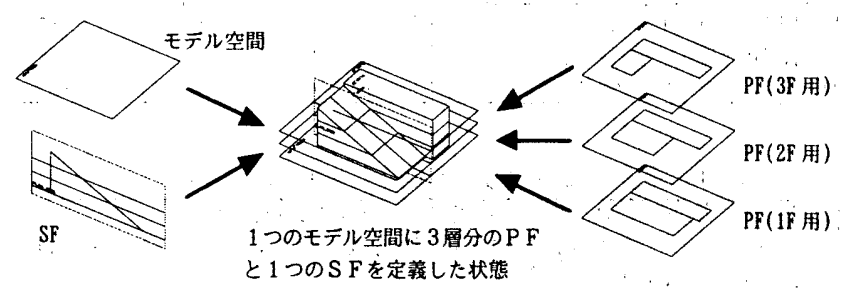

図31組のモテル空間、P F / S F の定義例

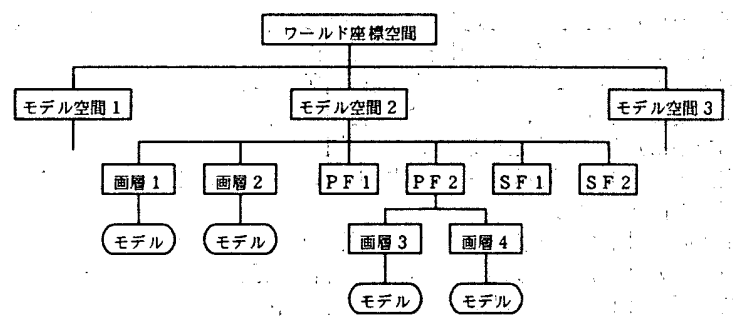

创えはこの龱では，モテル空間2の枠かラヘルを指示すれは，画周 $1 ， 2 ， 3 ， 4$ のモデル を，またPF 2の枠を指示すれは，画層了と4のモテルを一括して処理することができる。 图 4 モデル空間、P F / S F、及び画㟄の構成 
を指示することにより，モデル空間やP F ，S F を単位に画層の 表示状態を一括して処理できる。(図 4 )

（2）各モデルの定義・編集支援機能

(4) 平面モデル / 断面モデル : 両角らが提案したシステム文10)に通 り芯による図形制御機能を組み込んだものとし，作業は P F P S $\mathrm{F}$ 上で行う。通り芯, 部屋等の空間単位や, 床等の外形線を用い ながら定義する。平面モデルでは通り芯を編集することによって 空間オブジェクトの形状, 面積情報, 通り芯上に配置されている 壁や柱などの物的要素の位置や寸法が自動的に更新される。また， 各階の平面モデルは高さの情報を保持しており，作業平面上の各 要素を壁, 柱などの高さを持つ建築部材モデルに置換しながら層 単位の 3 次元モデルを構築していけるものとする。

(5) 外形モデル：曲面や不整形な建築形態を扱えるように，様々な 3 次元形状を定義・編集できる必要がある。

（6) 構造モデル：下川らが提案したシステム文11)の考え方を採用す る。具体的には, 通り芯, 部材配置線, ボリュームモデル, オリ ジナル・モデルという 4 つのレベルのオブジェクトで順次構造体 を定義する。通り芯を編集することによって，その上に配置され ている部材配置線, ボリュームモデル, オリジナルモデルの位置 や寸法が自動的に編集される。

(7) 論理演算可能な記述モデル: 平面, 断面, 外形, 構造の各モデ ルは，任意の作業平面の位置で断面図形を取り出したり，他のモ デルとの干涉チェックのため, 論理演算できる必要がある。

(3) 整合操作支援機能

(8) 複数モデルの重放合わせ/並列配置表示:モデル空間やP F / S $\mathrm{F}$ の基準点を合わせて異なるモデルを重ね合わせたり，枠をド ラッグして横に並べたりしながら調整作業を進めることができる。

(9) 断面図形取り出し: P F P S F を定義し, 断面図形の取り出し 命令を実行すると，モデル空間内の任意の断面図形がそのP F / $\mathrm{S} F$ 上に取り出される。この時, 断面図形を格納するための画層 がPF（SF）の下位に自動的に定義される。断面取り出しの対 象となるモデルが複数の画層に分かれている場合, 画層も複数定 義され，断面図形はそれぞれ対応する画層に格納される。(図 5 ) (10) モデルの複写：モデル空間同士，P F / S F 同士で指示したモ デルを自由に複写できる注14)。また, P F P S F 全体を他のモデル 空間に複写することもできる。この際, 対応する画層も自動的に 定義される。代案を生成したり，モデルを新規作成するための手 掛かりにしたり，異なるモデル同士で調整を行う場合に用いる。

(11) 干涉チェック：P F P S F上に定義された平面モデルや断面モ デル, 外形モデルや構造モデルなどを重ね合わせた際に，任意の モデル同士の干涉した部分 (交差した部分), あるいははみ出した 部分を取り出し，表示することができる。

(12) 通り芯によるモデル間の調整声 ${ }^{15)}$ : 複数のモデル空間やP F に 渡って，対応する複数の通り芯を順次選択した後，一括して編集 することができる。例えば，上下階の関連部分を一括して等量だ け変形させたりすることができる。

(13) モデル作成のためのオブジェクト変換 : 外形モデルから取り出 した断面図形を平面モデルや構造モデル用の通り芯に変換できる。

6. システムの試作

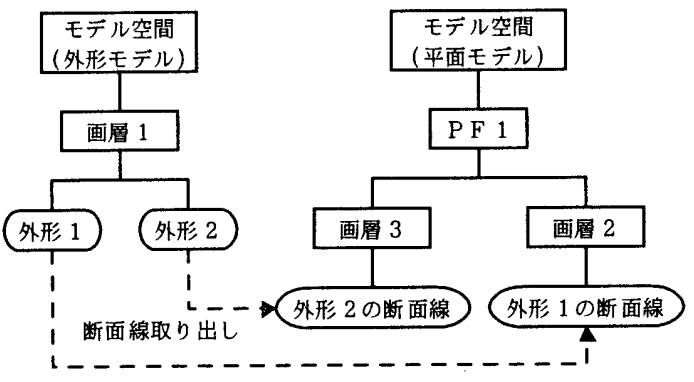

外形 1 と外形 2 という2 つのモテルの断面図形をP F 1 の作業平面で取り出すと,画層 2 と画層 3 のつの画層が自動的に定義され，それぞれ対応する断面線が格納される。

図 5 外形モデルと平面モデルの重わ合わせ作業の模式図

表 5 整合操作支援企画設計 C A D の基本仕様

1. モテルの定義空間

(1)モテル専用作業空間

(1)異なるモデルの個別定義, 分離, 一体化

(2)モテル単位の表示切り替え, 移動の一括処理

(2)作業平面

(1)ブランフェース（P F)，セクションフェース（S F)

(2)各階毎の平面モテルの一括表示切り替え, 移動

(4)断面図形取り出しとその後の一括表示切り替え, 移動

(3)画層定義

(1)モデル空間，P F / S F 毎の画層定義

(2)モテル空間, P F / S F 毎の画層の一括操作

2.モデ作成支援環境

(1)平面モデル

(1)複数階の並列デザイン

・P F間での通り芯の一括操作

(2)通り芯制御

・通り芯の編集による空間オブジェクの変形

(3)面積管理

(4)空間を単位にしたモテリング操作

(5)外形・楧造から取り出した断面形との干涉チェック

(6)スラブや柱, 壁などの3次元オブジェクトの配置

(2)断面モデル

(1)通り芯制御

(2)同一モテル空間内に定義済みのP F の自動位置表示

3)構造モテル

(1)具象度のレベルに応じたクラス階層

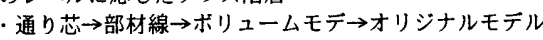

(2)通り芯の編集によるモデルの変形

・通り芯の編集によるボリュームモテルの自動調整（1軸方向） . 可変部分と固定部分の指定

(3)部材線の定義

(4)ボリュームモデルとオリジナルモデル

・置き換え操作によるオリジナル部材の定義

(5) P F / S Fによる断面図形の取り出し

・ボリュームモデルとオリジナルモテルのみ

(4)外形モテル

(1)外形イメージモデル

・全体形状，棟，外装など

(2)建築形態規制モデ(斜線制限モテル)

(3) P F / S Fによる断面図形の取り出し

(5)論理演算可能な記述モテル

(1)各モテルから論理演算可能なモテルへの置き換え

3. 整合操作支援機能

(1)複数モテルの重好合わせ・並列表示

・枠を指示して移動

・P F/S Fのモデル空間に対する自動位置合わせ

(2)断面図形の取り出し

・外形モデルからの断面図形取り出し

・構造モデルからの断面図形取り出し

・平面モデルからは 3 次元のオブジェクトが配置されている

場合に限って断面図形取り出しが可能

(3)モデルの複写

・モデル空間相互，P F / S F 相互でのモデルの複写

・ モデル空間相互でのP F/S F 全体の複写

(4)干涉チェック

・交差部分のチェック，はみ出し部分のチェック

(5)通り芯操作によるモデ間の調整

複数のP F 内の通り芯の一括操作 (移動, 回転)

(6)モデ作成のためのオブジェクト変換

・外形モテルから取り出した断面図形の通り芯への変換

※○はプロトタイブシステムで開発済みのもの,、は一部機能しているもの, ×は今後 開発予定の機能を表す。 
上記仕様に基づき，整合操作を支援する 3 次元 C A D システムの プロトタイプを試作した。システムはAutoCAD R14Jのカスタマイス 環境を利用して開発した。開発言語は AutoCAD 上で稼動するインタ プリタ言語であるAutoLispを使用した。平面計画を支援する機能は 両角らが開発したシステムに通り芯の生成・編集機能を組み込んた ものを構築，これを利用した。構造計画を支援する機能は下川らが 開発済みのシステムに，部材のボリューム・モデルや個別に形状を デザインした部材モデル（オリジナル・モデル）の断面図形を取り 出す機能を追加したものを利用した。外形検討を支援する機能は AutoCADの持つソリッドモデリング環境を利用した。この他, 新たに 次の機能を開発した。番号は前章の仕様の番号と対応する。

1) モデル空間と作業平面 (P F , S F ) の定義機能 (1), (2)

2 ) :モデル空間と P F / S F に合わせた画層管理機能 (3)

3 ) 構造, 平面モデルから論理演算可能なモデルへの置換機能 (7)

4) 複数モデルの重ね合わせ / 並列表示機能 (8)

5) S P F , S F を利用した断面図形の一括取り出し機能 (9)

6) モデル空間と P F / S F を利用したモテルの複写機能 (10)

7) 3 ) と連動した異なるモテル間の干涉チェック機能 (11)

8) 断面図形から通り芯への変換機能 ((B)

\section{7.ケーススタディとシステムの評価}

試作したシステムの有効性を確かめるため，4階建て商業ビル設 計のケーススタディを行った。図 6 はその主な過程を示している。

ケーススタディでは Pentium200MHz のC P U, メモリ $64 \mathrm{MB} の$ D O S / V 機を使用した。図6の囵で構造モテルの断面図形を 1 層 分取り出すのに 25 秒かかったが, 他の部分では待つという感じは なく, 実用可能な環境が実現できた。以下に，試行を依頼した設計 者の意見を含め，システムの評価を各段階毎に述べる。

1) (3) (4)の断面図形取り出しから面積確認へ至る過程では作業性 が格段に向上した。表 6 の(a)と(b)を比較すると，合計のステッ プ数は半分以下に減少しており，煩雑な画層操作も省略されたこ とが分かる。1つの階（P F ) でもステップ数は半減しており, 各 階の処理を考えるとその効果は大きい。また, PFPS F の枠で 平面モデルや断面モデルの位置を表示したことで，3 次元モデル に対する面の定義位置が確認し易くなった。

2) (5)〜6で，P F の枠をドラッグして平面モデルを並列に表示し たり,アクソメ画面で重ねて上下階の䡔がりを確認したりする一 連の操作は, 発想と一致して便利である。また, 複数階の通り芯 の一括編集機能により，平面モデル修正の作業効率が向上した。

3 ）アクソメあるいは透視図視点で表示した 3 次元モデルでは断面 形状が捉えにくかった。8のように，S F の導入で 3 次元モデル の任意の断面を容易に確認できるようになり, 平面モテルとの関 係も容易に読文取れるため,断面形状の編集作業が容易になった。 4 ) (9) (10では, 平面モテルや断面モテルで作成した通り芯を複写 して 3 次元的な構造部材の定義に利用できるので, 構造検討への 展開が容易である。

5) (11Dのように部材の断面図形が画面上に複数存在する場合でも， その断面図形を取り出したP F の枠を指示して一括して動かせる ので，平面モデルとの重ね合わせが簡単に行えた。

6 ) 全体的には, 外形モデル, 平面モデル, 構造モデルを独立して

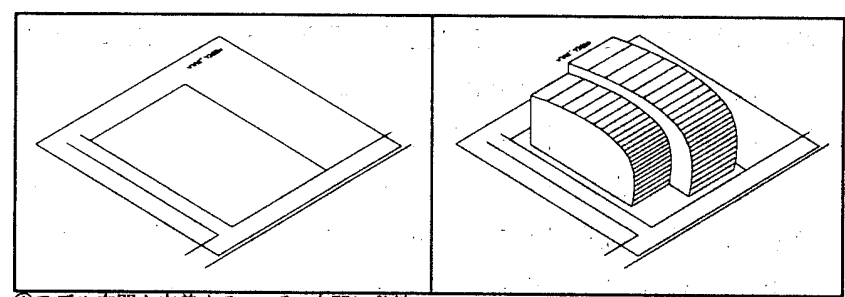

(1)モテル空間を定義する。モテル空間に敖地 (2)同様にモテル空間に外形モテル用の画層を 用の画層を定義し，影地情報を書き込む。定義し，標準のソリッドモテリンク機能で外 形モテルを作成する。

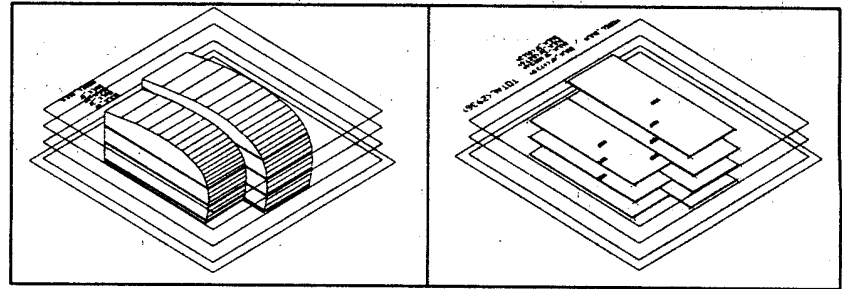

(3)平面計画用に 4 層のP F を定嶬する。それ (4)外形モデルの画層をOF Fにする。断面园 らのP Fで外形モテルの断面図形を取り出 形を通り芯に変換するコマンドで通り芯を生 す。 成し，通り芯で閉じられた領域に面積情報を 持つ空間単位図形と対応する休を定義する。

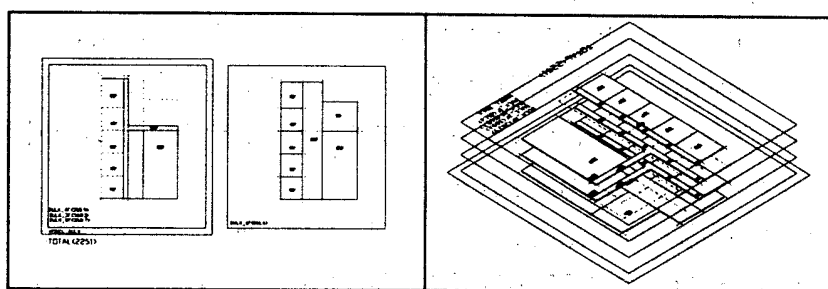

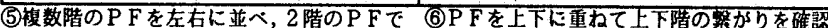
部屋等を定義する。それらの図形を各階のP する。图は大まかな平面計画が固まった段階。 Fに被写したり，通り芯をまとめて操作した アイソメ視点でも通り芯を動かすことができ りしながら平面計画を進める。 る。

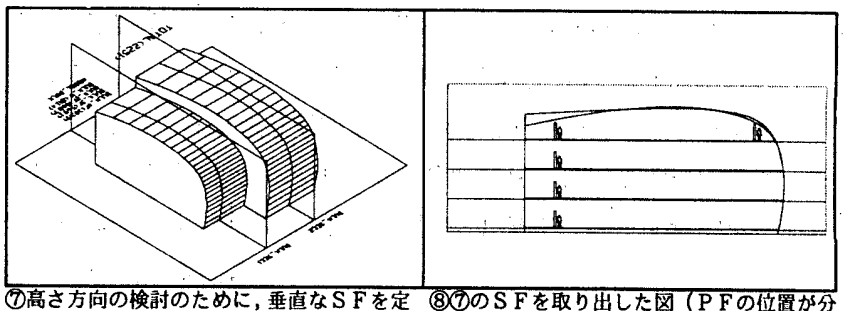

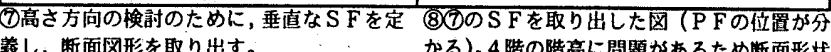
義し，断面図形を取り出す。: ‘功。4 階の階高に問題がるため䉼面形状 の修正作業をしている。この後, 新しい断面 図形を利用して外形モテルを定淁し直した。

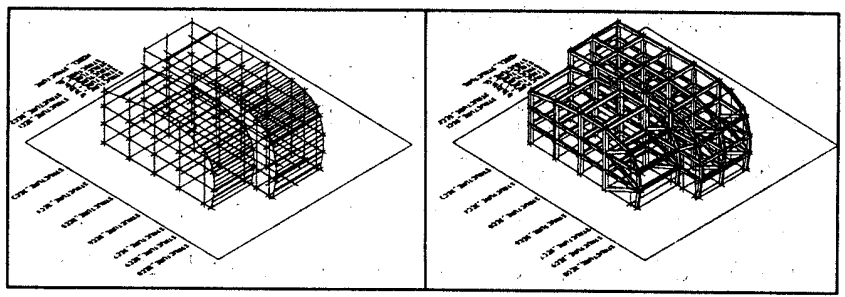

(9)平面で利用していた通り芯に加え，新たに (10通り芯の交点を参照しながら部材配置線を 定義したS Fから取り出した断面図形を通り定義していく。四は部材配固線上に大まかな 范に変換し，棈造檢討用の通り芯を定義す ホリュームモテルを作成しだところ。 る。

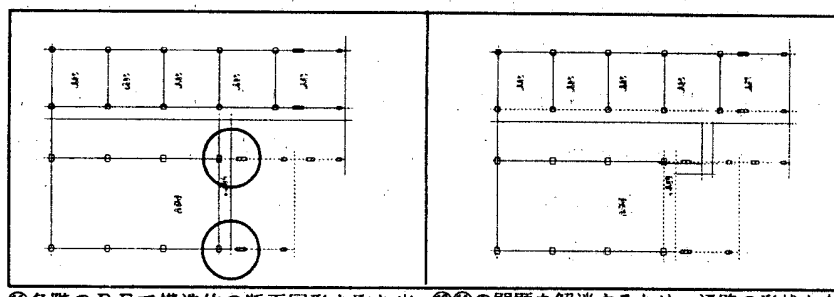

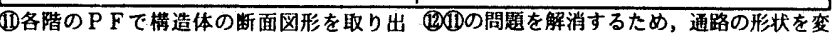
す。平面のP Fと重ね合わせたところ，3階 更する。

で通路とブレスの位置関係に問題があること

に気付いた(○で囲った部分)。 
表 6 プロトタイプシステムと市販 C A D の作業ステップ数比較 (a)プロトタイブシステムによるコマンド実行リスト

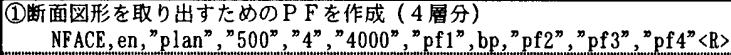
(2)

BSEC,pf1,pf2,pf $3, \mathrm{pf} 4$, en 1, en $2<\mathrm{R}>$

(3)断面図形を通り芯に変換 ( 4 缯分)

SEC2RL, "plan", "1000", sec1-1, sec1-2, sec2-1, sec2-2, sec 3-1, sec 3-2, sec4-1<R $>$

(4) 4 層の通り芯で囲まれた領域をクリックし，空間オフジェクトを定義

$S P, " z o n e ", p 1, b p<R>$

(5) 3，2，1層の煩にアクティフな P F を桨更し，(4)と同様に空間オフジェクトを定義 CHFACE, pf $1<\mathrm{R}>/ \mathrm{SP}, \mathrm{p} 1, \mathrm{p} 2<\mathrm{R}>/ \mathrm{CHFACE}, \mathrm{pf} 2<\mathrm{R}>/ \mathrm{SP}, \mathrm{p} 1, \mathrm{p} 2<\mathrm{R}>/ \mathrm{CHFACE}, \mathrm{pf} 3<\mathrm{R}>/ \mathrm{SP}, \mathrm{p} 1$, $\mathrm{p} 2<\mathrm{R}>$

(b)市販の汎用 C A D *1によるコマンド実行リスト

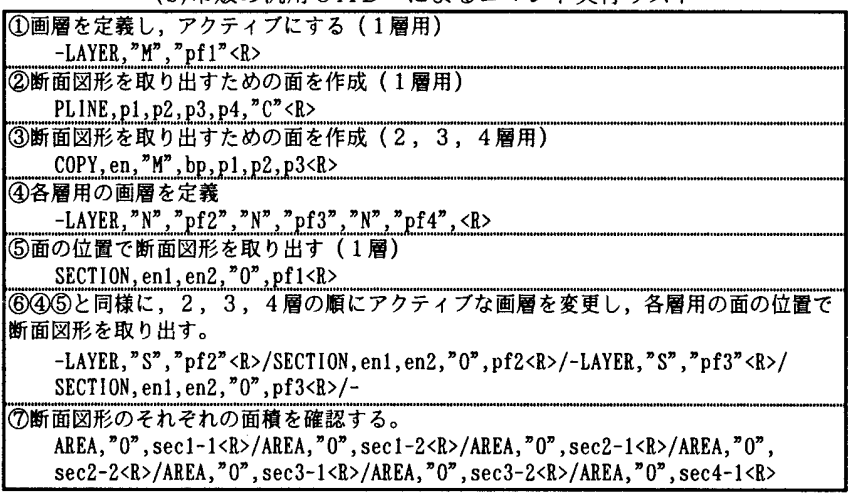

(a)のコマンドは全てオリジナル。”,”で区切られた最初のフィールドはコマンド名を，それ に続くフィールドはオブション選択, 図形指示, 文字列入力なと, 行末の〈R〉はコマンド終 了,/はコマンドの区切りをそれそれ表す。 *1:AutoCAD R14J

作成できるため，整合性を取ることに拘束されて思考が中断しが ちな従来の手法に比べ,自由にモデリングを進めることができた。

\section{8. 結論}

本研究では，整合操作による設計プロセスのモデルを定義し，モ デル空間と P F / S F ，及びそれらを利用した整合操作支援機能を 構築した。ケーススタディとその評価を通して以下の知見を得た。

（1）検討内容に応じた複数のモデルを使って,並列的に作業を進め ながら徐々に整合性を取っていくような設計方法を想定したシス テムを提案し，その実用可能性を確認した。

（2）想定した設計方法が採用されるケースは多いと考えられ，今後 多くの設計業務への活用が期待される。

一方，次のような点が今後の課題として挙げられる。

（3）平面モデルや構造モデルを定義するシステムは曲線の通り芯を 扱えないので，作成できる建物の形に幾つか制限がある。

(4) 断面図形取り出しの際に見え掛かり部分の投影図が取り出せな いので，平面計画への影響を検討する際に情報不足である。

今後, 上記のような課題を踏まえ, システムの試用と改良を繰り 返しながら，実用性を更に上げていきたい。

\section{謝辞}

侏佐藤総合計画（元熊本大学大学院生）の浜田智紀氏には, システムの構想, 開発において多大なこ協力を頂いた。心より謝意を表したい。

注

1) 日本建築学会設計方法小委員会によって定義された設計プロセスモテル文 12)では, 観点の代表例として「動線」「「平面型」「規模」「構造」「設備」, 「造形」が挙げられている。

2) アメリカの設計事務所 5 社, 国内のゼネコン（設計部） 2 社, 設計事務所 4 社を訪問し，アンケートとヒアリングによる調査を行った。
3）山口は文 13)の表一1等で, 企画設計の特幑の一つとして, 㖟眜で粗い表現 のモデルを使って試行錯誤しながら問題発見的に設計案をまとめて行くこと を挙けている。

4) これは複数の設計者が使用する複数の C A D システムとの連携の問題とも 考えられるが,通信の問題を含むことになるので,当面は一人のユーザが使 用する 1 台の C ADシステムの問題に限定して考える。

5) 三菱地所のDELTA, 渡辺らのOOAMS 等の知識表現モデルの研究や, 大成建設のLORAN-T, 東京電力のAPLUS, 長澤らのI B D , > ジタのCOMPAS S等の建物モテルの統合化の研究が挙げられる。

6) 架構方式, 部材寸法, 部材形状の検討を段階的に支援する。応力解析など の力学的検討は扱っていない。

7) 設計過程や分析の詳細については文献 14 と文献 15 を参照。

8）事例 1 では, AutoCAD GX- III と当研究室で当時開発が進められていたモテ リング・システムを用い，事例2ではAutoCAD R13Jを用いた。

9）設備や構造に関する技術的検討，樍算などの作業も想定できるが，今回は 取りあえず建築の物的形状の直接かかわる事項に限定して考えた。

10) AutoCAD やFORM-Zでは「セクション」というッールが, MiniCADでは「切 断面を生成」というッールが用意されている。

11）モデル空間の範囲（長方形）は定義時に対角点を指示して決定する。また， 対角点を指示する際の 1 点目がモデル空間の基準点となる。

12）モデル空間の定義時にモテル空間の名称を任意に設定すると，その名称を 表示した文字図形 (ラベル)を任意に配置しておくことができる。モデル空 間が複数重なっている場合はこのラベルでモテル空間を制御する。

13）S F の枠の水平長さはモデル空間との交差部分を示し, 高さは利用者が任 意に指定する。

14）複写元と複写先のモデル空間の基準点が複写の際の基点と目的点となる。

15）現段階では異なるモテル間の通り芯の連動は考虑していない。

\section{参考文献}

1）長倉威彦他：現代建築の発想，丸善株式会社，1989，pp.252

2）藤原篤, 松本伸洋, 川畸清: 福井県立大学基本計画・基本設計（福井キャン パス）における合意形成のプロセス，日本建築学会計画系論文集第 452 号, 1993.10, pp. 85-94

3）西郷正浩，ほか 2 名: 3 次元企画設計ツールのための空間記述モテルに関す 万研究, 日本建築学会計画系論文集第 499 号, 1997.9, pp.237-243

4) David Kurmann : SCULPTOR - How to Design Space?, CAADRIA98 Proceedings, 1998.4, pp.317-325

5) Kevin Matthews : A Model for Integrated Spatial and Structural Design of Buildings, CAADRIA98 Proceedings, 1998.4, pp.123-132

6) W. J. Miitchell, R. S. Liggett, Milton Tan : The Topdown system and its use in teaching --an exploration of Structured, Knowledge-Based Design--, ACADIA Workshop Proceedings, 1988, pp. 251-262

7) Markus Bonn : Modeling Architectural Forms Through Replacement Operations, ACADIA89 Proceedings, pp.103-130

8) 高本考頼: 建筑要素の関係設定に着目した知的 C A D の開発研究, 熊本大学 学位論文, 1993.3

9) Branko Kolarevec: Relational Descritption of Shapes and Form Generation, CAADRIA97 Proceedings, 1997.4, pp.29-39

10) Mitsuo Morozumi, Yuichi Shimokawa, et al. : On the Development of 3-D Schematic Design System -Utilities for Planning Sketches and 3-D modeling-, CAADRIA96 Proceedings, 1996.4, pp.63-73

11) Yuichi Shimokawa, Mitsuo Morozumi, et al. : Replacement and Transformation as a key to Schematic Design Thinking -3-D Modeling System which Supports Design Thinking--, CAADRLA98 Proceedings, 1998.4, pp.365-374

12）原広司, 鉿木成文, 服部岑生, 太田利彦, 守屋秀夫: 建築学体系 23 建築 計画, 彰国社, 1982, pp.200-217

13）山口重之:設計の流れと C A D / C G 建築 C A D / C G 活用ノウハウ, デ ルファイ研究所, 1993, pp.8-11

14）両角光男 : 建筑設計の新しいかたち, 丸善株式会社, 1998

15）下川雄一, 両角光男, ほか 6 名: 建築設計におけるデザインの整合操作の 考察 〜設計思考に対応したCADシステムの開発に関する研究〜,建築 学会研究報告九州支部, 第 37 号・ 3 計画系, pp.141 144, 1998.3

（1998年 7 月10日原稿受理，1998年 9 月 9 日採用決定） 